stress relations and breakage of rocks, of their properties in conditions of triaxial stress and also the porosity and strength of brittle solids with particular reference to gypsum. These papers show a real attempt to correlate experimental results with theory, but it must be appreciated that many of the derived formulæ must, for the present, represent only an empirical interpretation of the properties and that much work is still to be done before the course of changes induced by applied stress can be forecast with any degree of accuracy.

Session 2 was devoted to consideration of "Elasticity and Creep". Papers were given on the elasticity, creep, shrinkage and the effect of rate of loading on some mechanical properties of concrete. The strength of ceramic materials under impact testing and sonic testing, and the stress-strain relationships in heavy clay products were discussed, while the factors effecting the thermal shock resistance of hightemperature materials were also considered. Measure. ments of the rheological behaviour of coal, together with the measurements of its dynamic mechanical properties, were compared with the paper presenting the elastic and plastic properties of carbon and graphite.

In the third session the conference went on to consider "Dynamic Loading, Impact and Fragmentation". Here papers were presented on the exploratory tests on the strength of concrete beams under pulse loads, impact testing and roller bit penetration. The breakage of natural materials was considered generally and in detail with the fragmentation of explosive detonated in stone blocks and with the partition of energy in a blasting shot. From the coal industry, studies of the size distribution and relationship between dust formation and coal strength provided an alternative approach.

Session 4 was devoted to a consideration of the "Action of Tools". There was a basic paper on friction between coal and metal surfaces and the forces required to penetrate the brittle material with a wedge-shaped tool. This was followed by a paper on the effect of lateral pressure on the cutting of coal by wedge-shaped tools and a consideration of both the theoretical and practical aspects of coal ploughing.

The discussions which followed papers and sessions have been admirably condensed and the whole volume will be an important work on the shelf of all who are concerned with understanding the processes in which the properties of brittle materials have to be taken into account.

David Train

\section{CONSERVATION IN AMERICA AND AFRICA}

Conservation of Natural Resources

Edited by Guy-Harold Smith. Second edition. Pp. xi +474. (New York: John Wiley and Sons, Inc.; London: Chapman and Hall, Ltd., 1958.) 68s. net.

\section{The Conservation of Natural Resources}

By Richard C. Haw. Pp. $256+36$ photographs. (London : Faber and Faber, Ltd., 1959.) 30s. net.

TN every part of the world, though in varying 1 degrees, the now obviously rapid increase in population consequent upon the fact that the spread of the knowledge and practice of death control has outstripped knowledge and practice of birth control is forcing attention on the need to conserve or to use wisely all natural resources. In the second edition of "Conservation of Natural Resources" the editor, Guy-Harold Smith, repeats the warning, "every individual company, or organization must share in the task of preserving the resource base upon which the American economy has been built. What is needed is an enthusiasm and an understanding of the essential nature of resources and the measures necessary to save from wasteful destruction our national heritage." It may be claimed that conservation in America was a by-product of the great economic depression of the nineteen-thirties which happened to coincide with disastrous seasons producing dust-bowl conditions over vast areas. Although ghost-towns already spoke eloquently of the exhaustion of mineral riches, abandoned farms of the retreat from the 'frontier' or 'pioneer fringe', conservation became identified with the prevention of soil erosion. An America which had been taught to think in square-mile blocks had to realize that Nature abhors a straight line, and to find answers in contour ploughing, strip cropping, restitution of grass cover thoughtlessly ploughed or woodland unwisely cleared. Now conservation has come to mean much more. The sixteen authors of this survey cover in its eight parts the land (with soil, irrigation, and grassland), the forests, water, minerals, wild life, recreational resources (linked with the conservation of man) and so to national, state and local planning.

Prof. S. S. Visher has an interesting introductory chapter on the public domain. It is perhaps not commonly recognized that practically all United States territory, except for the closely settled land of the original thirteen States, has, at one time, been Federal property. Forty-one per cent was sold to individuals for cash, 27 per cent granted to homesteaders, 13 per cent given to the railroad companies, 12 per cent given to education authorities, 1 per cent for canals, leaving 6 per cent, mainly of wet lands, which passed into ownership of the States. In 1956 more than $400,000,000$ acres remained or had reverted to public ownership, being a total not far short of that in improved farm land. Thus Federal and State authorities are able to give a lead to conservation in the national forests and the great grazing lands as well as in national parks and Indian lands. But on privately owned land there are conflicting interests. Individual success is still measured largely by wealth : the obvious temptation is the quick fortune from 'mining', whether it be of minerals, the soil, or the forests. Technological advances will take care of the future and with the present over-production of agricultural commodities, those who preach conservation or teach it in the universities have by no means a pre-converted audience. This fine book should serve them well.

Although with an identical title, Mr. Richard C. Haw's book is very different. He is an instructor in the Domboshawa Government School at Salisbury in Southern Rhodesia: he writes essentially of the African veld and of the vital, urgent, necessity of its proper management if Africa is to survive. He uses the University Farm at Salisbury West as an example of planned layout; chapters which follow are practical guides to surveying, soil conservation, manuring, reclamation, road construction and water conservation. It is significant that he, too, does not forget the importance of wild life. Since so much of the world's problem lands lies in the seasonally dry sub-tropics, Haw's book deserves a wide public in other continents. $\quad$ L. DUDLEY STAMP 